\title{
Visual Grounded Theory: A Methodological Outline and Examples from Empirical Work
}

\author{
Krzysztof Tomasz KONECKI \\ Institute of Sociology, University of Łódź, Poland \\ krzysztof.konecki@gmail.com
}

\begin{abstract}
Grounded theory has not usually been associated with the extensive use of visual data. The author of the paper wants to present a basic introduction to methodological concepts and procedures, which allow researchers to incorporate visual data in their analyses while designing their research projects within the framework of grounded theory. The author also discusses the different approaches of visual data analysis that use the name of grounded theory but do not in fact perform the analysis according to its basic principles. At the outset, the author describes some inspirations that have come from a few researchers who have used the visual data in constructing theories in the grounded theory methodology style of analysis. The status of visual data and a methodological model of visual data analysis in grounded theory (multislice imagining) is also described. The multislice imagining is a grammar of visual narrations analysis that accents the following stages: a) an act of creating pictures and images (analysis of context of creation); b) participation in demonstrating/communicating visual images; c) the visual product, its content and stylistic structure; d) the reception of an "image" and visual aspects of presenting/ representing something. Next, procedures of analyzing the visual data to generate categories on visual processes (transcription, open coding and memo writing) are presented. The presentation is based on examples from the author's two research projects on a visualization of yoga practice and on a visualization of homelessness. The author also presents a selective coding of visual cases and empirical materials together with theoretical memo examples and comparative analysis. The last described procedure is a theoretical sampling indicating how and where to look for visual data to generate the properties of the category. The paper will end with conclusions and some remarks on future prospects of visual grounded theory.
\end{abstract}

Key words: visual grounded theory, visual studies, visual ethnography, visual data, qualitative research, qualitative data analysis

\section{Introduction - What is visual grounded theory?}

The growing popularity of visual studies among qualitative researchers merits our attention, even if we do not share the widespread belief that 
a "digital turn" or a growing saturation of the material environment with visual communications (Clarke, 2005) have put images on a par with words in constructing narratives, not only in multimedia but also in research practices. ${ }^{*}$ Sociologists often mention that we increasingly rely on visual means (e.g. symbols, logos and trademarks) in contemporary cultures for defining and communicating our identities and social worlds.

Our increasing reliance on visual aspects of communicative interactions and the increasing frequency with which visual metaphors are employed in order to communicate our "live" experiences turn our attention to such artefacts as photographs, photo albums, video recordings, paintings, graffiti, photo blogs, video blogs, etc. Qualitative sociologists interested in conducting research within the framework of visual grounded theory need not worry about a shortage of data.

Grounded theory methodology (GTM) focuses on generating/constructing theories from empirical data through research understood as a reiterative process - with a researcher cruising between field data deposits (e.g. libraries, online resources) and his or her analytical workshop. ${ }^{1}$ Having analysed a batch of data, the researcher returns to the field for more data, traced with the insights provided by previous analyses. Data are coded, conceptual labels honed and theoretical categories constructed. As the point of "saturation" of categories is approached, data collection gives way to defining and conceptual refinement. (Glaser and Strauss, 1967; Glaser,

\footnotetext{
* The author would like to thank to two anonymous reviewers for their valuable comments and suggestions that helped to improve the quality of the paper.

${ }^{1}$ There is controversy in discussions on GT if it is inductive (we can generate theory) or abductive methodology (abduction is when we reformulate our previous knowledge and construct theories). Grounded Theory can therefore be treated as an abductive methodology because it includes rational reasoning on empirical data to formulate a theoretical argument, which continues to be tested experimentally. This idea, which combines the methodology of grounded theory with abduction is presented in the later work of A. Strauss, which refers to the concept of there, i.e., Charles Peirce's abduction. Although it should be mentioned that it is only a reference to the inductive part of the abductive reasoning, i. e., it indicates the great importance of a prior experience of the investigator (cf. Strauss, 1987: 12). When a new and unique empirical observation cannot be explained on the basis of existing knowledge and categories or assumptions, existing knowledge must be reformulated and re-sorted for an explanation of a new fact. Abduction is the process of innovation by modifying the emerging theory and new segregation of elements of present knowledge. Scientific discovery always requires the integration of previous knowledge with new experiences. Reconstruction of existing knowledge in new ways with the addition of new observations builds abductive inference. This new scheme should undergo modification and does not allow for the enforcement of empirical data, i.e., their artificial matching to existing concepts and theoretical schemes. From this point of view we can call GTM abductive methodology (Kelle, 2005: 31; cf. Strübing, 2004, 2007; Bryant, 2009; Reichertz, 2010).
} 
1978; Strauss, 1987; Strauss and Corbin, 1990; Charmaz, 2006). GTM is very popular among qualitative researchers. It gives the possibility to create theoretical statements during empirical investigation. Researchers become more courageous in the formulation of generalizations based on qualitative data. It also provides tools for researchers to analyze qualitative data in a more rigorous way while giving them some freedom to decide the direction of analysis. Some of the procedures of GTM have also penetrated other strategies of qualitative data analysis. Researchers today often do not recognize the origin of procedures, as for example a procedure of theoretical saturation and/or theoretical sampling in ethnography. The popularity of GTM does not go hand in hand with the popularity of visual studies. GTM researchers rarely use the visual data to generate generalizations. We want to compensate for the lack by showing the benefit of connecting the GTM with analysis of visual data.

Grounded theory has not usually been associated with the extensive use of visual data. Presenting a visual grounded theory requires a basic introduction to methodological concepts, which allow researchers to incorporate visual data while designing their research projects within the framework of grounded theory. Visual grounded theory, in turn, relies on visual data for constructing categories, describing properties and generating/constructing theoretical hypotheses, which account for the visual phenomena and visual social processes. Principles and procedures of visual grounded theory proposed in the present paper are evidence-based and have been derived from my own research and from the slowly growing research literature on this topic.

We present in the paper the possibility of doing the visual analysis by using the GTM. First, we describe some inspirations that come from a few researchers who have used the visual data in constructing the concepts in GTM style of analysis. We will also describe the status of visual data analyzed together with presenting a methodological model of visual data analysis in grounded theory (multislice imagining). Next, procedures of analyzing the visual data to generate categories on visual processes (open coding and memos writing) will be presented. The presentation will be based on the examples from our two research projects on visualization of yoga practice and on a visualization of homelessness. There will be a presentation of selective coding of visual cases and empirical materials together with theoretical memo writing examples and comparative analysis. The last described procedure is a theoretical sampling indicating how and where to look for visual data to generate the properties of the category. The paper will end with conclusions and some remarks on future prospects of visual grounded theory. 


\subsection{Visual data analysis and grounded theory}

Visual data has been quietly but consistently neglected both as a potential primary and potential auxiliary source for generating/construction GT. It is difficult to explain that, in spite of the "visual turn" in social communications at the end of the 20th century, so little theoretical attention was paid to visual data in grounded theory studies. Maybe the reason has been that social research, in general, has been based mainly on analysis of textual data supported largely by statistical methods. Interpretation of pictures and visual data has been difficult to elaborate quantitatively. Only the last two decades of strong growth of visual research in the social sciences influenced to launch visual analysis in GTM. But still there are only seeds of visual data analysis using the procedures of grounded theory methodology.

Whatever works helping a researcher generate theory - can acquire the status of "data" (Glaser, 2002). One can rely on interviews or observations, movies or newspapers, archive documents, popular fiction and the Internet to generate categories and list their properties. Charmaz points out that a researcher's activities and the context of a research project influence the data that emerge from it, and so does their theoretical knowledge and the perspective they choose to adopt (Charmaz, 2006; Puddephatt, 2006).

Among those few examples of combining grounded theory with visual data research, which merit attention as notable exceptions, a study of grounding visual research in shooting scripts (Suchar, 1997) stands out. Shooting scripts are lists of research topics or questions, which can be examined and answered by collecting and analyzing photographic information within the framework of a photo-documentary project (Suchar, 1997: 33). The research strategy follows the interrogatory principle: a researcher attempts to answer research questions by photographing particular objects (Suchar, 1997: 34) and by analyzing these photographic data in order to find patterns and start conceptualizing. Granted, Suchar's approach seems to belong more to ethnography or to Qualitative Data Analysis (QDA) than to GT (cf. Glaser, 2004). He is concerned about "worrisome accuracy" (Glaser, 2002): "The process of interrogating images and examining field notes provides a means of intellectually interacting with documented observations. This is a creative and thought-provoking process. We can also 'check' our interpretations against other data, including our observed subject's interpretations, to reduce script-based bias" (Suchar, 1997: 39).

Suchar's research seems to be closer to photographic fieldwork and an exercise in ethnography and QDA than to a GT approach. However, he provides an interesting example of the uses of conceptualizing visual data, and GT could profit from following it in order to sensitize its concepts: "I also 
argue that the grounding of conceptualization in specific visual referents qualitatively enhances the grounding process itself. I have found that reference to very detailed visual documents, and the information they contain, allows for a closer link between the abstractive process of conceptualizing and experientially derived observations" (Suchar, 1997: 52).

Suchar finishes his analysis at the conceptualization stage. We do not see the theoretical framework emerging from his analysis. The analysis is not so much immersed in comparing the objects and concepts to create the dense and coherent theory or theoretical statements. Some qualitative data analysis and theoretical descriptions are given, mainly to explain the ethnographic findings.

A more direct attempt to match visual data and grounded theory inspiration has been made by Adele Clarke (2005), who announced her departure from the basics of GT and proposed concentration on situational analysis using visual materials. Clarke wants to combine critical and empirical paradigms in visual research. She is interested in gender-related gazes, in the process of othering, and in the orientalization of gaze with imperial connotations. She wants to trace gazes of power. ${ }^{2}$ She recommends four steps before the analysis begins: deciding, locating, collecting and tracking the materials best suited to the researched situation (Clarke, 2005: 223). Next, she proposes to analyze the images and to write analytic memos about them. She distinguishes three kinds of memos, which can subsequently serve as narrative data to be coded (Clarke, 2005: 224-228):

- "locating" (who produces an image, for what audiences, from which social world),

- "the big picture" (first impressions, writing the narrative description of the image, dividing the picture into a smaller parts to describe details),

- "specification" (deconstruction of the image by observing the image in different ways and getting outside the frame through which we are supposed to view the image).

Adele Clarke suggests plotting situational maps of visual materials: "Your situational map should include all analytically pertinent human and non-human, material, and symbolic/discursive elements of a particular image" (Clarke, 2005: 229). She suggests enriching the maps with elements not directly visible in actual photographs, but detected by a researcher in

\footnotetext{
${ }^{2}$ Gazing and an aesthetics of power connected with it, could also be traced in many interactions and/or in parades, holidays, spectacular celebrations and even in embodied gestures such as the Roman salute in the Fascist period in Italy that has been a sign of loyalty, dynamism and the efficiency of the regime (Griswold, 2008: 175).
} 
the researched field. These may include different implicated actors, actants, and institutions.

Clarke presents a case study of research on visual discourse. She is interested in the "medical gaze" by historical reconstruction of anatomy atlases used in medical education. She treats anatomy as a discipline in Foucault's sense, i.e., as a way of subjecting seeing and gazing to a discipline. Positional maps of pictures in atlases show that the presentation of anatomy at the beginning of the 20th century emphasized reproduction (not sexuality) and that some parts of body presentation were deliberately left unclear. Clarke carries out theoretical sampling and looks for contemporary presentations of anatomy atlases (CD-versions edited for educational purposes). Her analysis demonstrates that they are more sex-education oriented and that sexuality is stressed in positional maps.

Visual discourse analysis on the anatomic presentation shows that genital size is a synonym for the physical superiority of men. The female may or may not have a clitoris while the male always has a penis and the penis is a centre of narration. Heterosexuality is always assumed and the presentation is always connected with two sexes, erasing such sex variations as hermaphrodisms / intersexualities / transsexualities. "Males are largely visualized as sexual, while females are reproductive" (Clarke, 2005: 255).

Clarke used some procedures of GT (coding, theoretical sampling, theoretical memoing) in her visual discourse analysis. However, she also engaged in a situational analysis of visual materials and "grounded theorizing", as she calls it, stopping short of the construction of a grounded theory. Nevertheless, she clearly demonstrates that the theory of a visual process in the "construction of disciplined gazing" is feasible. It could be built if we engaged in more theoretical sampling and performed a more systematic comparative analysis, and ultimately obtained more data from fieldwork in constructing images. Clarke's technical suggestions and the style of her detailed analysis can be very useful and instructive for grounded theoreticians, although her analysis is not classical grounded theory. She concentrates mainly on a situation, which is always complex and fuzzy and she does theorize about the situation rather than construct a theory.

Another case of a quite successful combination of visual studies with GTM can be found in Cornelius Schubert's (2006) grounded theory approach to a "video-graphic" field study in a hospital setting. We are of the opinion that Schubert has made a significant contribution to visual grounded theory. Schubert analysed video recordings of anaesthetic work during surgical operations using the grounded theory approach. He used the procedure of theoretical sampling by "selecting comparison groups". His 
comparative entities were interactions in mixed teams (humans and nonhumans) in numerous operating theatres. Schubert tried to organize the data from his fieldwork by writing content $\log s$ of video recordings. Content logs are "rough descriptions of the filmed situations and may contain references to analytical concepts" (Schubert, 2006: 120). Theoretical saturation is achieved through sampling and identifying of ethnographic "chunks" of described processes and through the content logs coding the data. Later on in his research, video-based interviews were carried out in order to describe the social, technical and medical perspectives of doctors of medicine. All of these materials were "slices" of data allowing the researcher to refine theoretical categories (Schubert, 2006: 123).

\subsection{The status of visual data in visual grounded theory - the reconstruction of "multislice imagining"}

How does grounded theory treat visual data and visual data analysis? Let us examine several logically and empirically possible combinations. Some of the possibilities are based on the empirical instances of visual data analysis, while some of them are just logical possibilities to analyse visual data with grounded theory methodology. The main criterions on the list of combinations are the following: a) are visual data auxiliary or the main source of materials for analysis with GTM?; b) is there the research on only visual processes or also on the others?

The least we can do (the first combination) is to analyse visual data as auxiliary materials in our GT projects to generate theories of actions and interactions or other processes. The analysis of, say, the social organization of ballroom dancing could definitely be enriched by visual methods and visual data: "The knowledge and experience that are gathered inside the body, make it impossible to express them verbally. That is why I made photos during interviews and I showed photos made on dance contests to my interviewees asking them what they could see and how they interpreted presented situations" (Byczkowska, 2009: 105).

The second possible combination of visual data research and GT analysis involves the use of visual data as the main source of empirical materials (along with the other kinds of auxiliary textual data) to generate categories describing actions and interactions. Research project of this type have been carried out to investigate interactions between humans and animals (Konecki, 2008a; Konecki, 2008b). The analysis focused on visual clues, e.g., gestures exchanged to create a psycho-social bond between humans and their pets. Visual data were the main source of data for the analysis of categories. Video recordings were accompanied by ethnographical work 
and an analysis of contextual and cultural patterns of interactions (Konecki, 2008a; c. f. Goode, 2007). ${ }^{3}$

Suchar (1997) used a similar approach, treating visual data as the main source of evidence in his research on the gentrification process. He had collected photographic data of physical objects (houses, facades, walls, house decorations) to generate the category of the "gentrification" of the urban environment. This category has been constructed with the aid of photos analysed to detect urban "romantic" motives in architecture. Visual data allowed Suchar to detect Victorian styled housing exteriors, animal iconography associated with heraldic symbols, exterior art work, decorative walls, gates, and fences. Comparing the photos and doing photo-elicited interviews gave him a possibility to notice patterns in the process of urban gentrification.

The third possible combination implies the use of visual data alone for the analysis of actions and interactions (without ethnographic and other auxiliary data); however, nobody has done such analysis in GT tradition so far. The fourth combination is connected with the usage of visual data either as an auxiliary or as the main source of empirical evidence, but only in the analysis of the visual dimension of actions and interactions. In the latter case, the visual data trump other kinds of data (however, such an analysis has not been performed in pure GT tradition so far). The last combination adds the possibility of using visual data to track visual actions and interactions. Visual processes could be tracked through photo albums, video blogs, photo blogs, but also CD-ROMs, or anatomical albums (cf. Clarke, 2005: 230-257) or even through drawings (Strauss, 1976: 6-12, where the symbolic visualization of the city is analyzed). This fifth approach seems to be at the core of visual grounded theory, because it focuses on theories of visual processes and visual actions and interactions.

Let us discuss the use of visual data as the main source of empirical evidence gathered in order to generate a visual grounded theory. What do we do when we visualize? First, we are always busy visualizing "something". There is a visualization of homelessness or of identity, a visual individualizing of our

\footnotetext{
${ }^{3}$ The analysis of gestures and their sequences is very important in understanding an activity organization. Video analysis helps in detailed analyses of the sequences and exchange of gestures in the interaction (Heath and Luff, 2007a, 2007b; Knoblauch, 2008). The analysis of the situations in situ also gives clues to understanding the emotions as constructed social practices that are organized by nonverbal gestures in specific sequences of interactant activities (Katz, 1999: 87-141).
} 
body, a visual gentrification of an urban environment, a visualization of a sports practice, a visualization of scientific achievements, a stylization of the body (make-up, piercing, body-building), visual persuasion (as in marketing, PR or commercial advertising), "construction of disciplined gazing" (as in "scientific discourse on sex"), visualization of intellectual disability, etc. Data emerge from the scaffolding of one's theoretical questions, suppositions and assumptions, often also from implicit everyday life assumptions (see: Emmision and Smith, 2000; Clarke, 2005). We can see the objects in many slices. Observation, at face value, can be enriched by slow and careful description of a picture and its coding. What is important in analyzing visual data is this reconstruction of the multislice imagining of reality in visual representations and their contexts. Slices of data are different source of data on the same phenomenon, after they have been conceptually elaborated: "In theoretical sampling, no one kind of data on a category nor technique for data collection is necessarily appropriate. Different kinds of data give the analyst different views or vantage points from which to understand a category and to develop its properties; these different views we have called slices of data" (Glaser and Strauss, 1967: 65).

In the approach that we took, multislice imagining is different. We perform "multislice imagining" assuming that visual data are multi-layered. All layers should be analyzed in order fully to conceptualize the visual processes. This assumption is a projection of our vision of multilayered reality and echoes the claim that reconstructing multilayered phenomena is the main goal of qualitatively generated social theory. Different kinds of data are layers delivering different points of view to any researcher, according to Glaser and Strauss. However, it is not enough to analyse the visualization processes. The processes are too complicated and not always verbalized. Understanding of the visual process is possible only by the full description of the multilayered context of visualization. The multislice imagining is the methodological device based, of course, on the theoretical meta-perspective that is the symbolic interactionism and especially the theory of social worlds (Strauss, 1978; Becker, 1982). The visualization of something as it happens in social worlds, or social gatherings/interactions, or social institutions, or any social space involves:
A. An act of creating pictures and images (analysis of context of crea- tion);
B. Participation in demonstrating/communicating visual images;
C. The visual product communicated, its content and stylistic struc- ture (perceived differently by different recipients, who are active co-creators of visual images);


D. The reception of an "image" and visual aspects of presenting/representing something. ("slices" of the visual dimension of the psychosocial processes).

Table 1. Multislice imagining and corresponding research, replication and coding procedures

\begin{tabular}{|c|c|c|c|}
\hline Slices & Research Procedures & $\begin{array}{l}\text { Replicative } \\
\text { procedures } \\
\text { (changing visual } \\
\text { data to textual } \\
\text { data) }\end{array}$ & $\begin{array}{l}\text { Analysis } \\
\text { / coding / } \\
\text { memoing }\end{array}$ \\
\hline $\begin{array}{l}\text { A. Act of } \\
\text { creation }\end{array}$ & $\begin{array}{l}\text { Collecting data - } \\
\text { observation and/or } \\
\text { reconstructing of the } \\
\text { act of image creation }\end{array}$ & $\begin{array}{l}\text { Possible } \\
\text { transcription of } \\
\text { data }\end{array}$ & $\begin{array}{l}\text { Analysis of the } \\
\text { inner context of } \\
\text { image }\end{array}$ \\
\hline $\begin{array}{l}\text { B. Participation } \\
\text { in demonstration } \\
\text { - communication } \\
\text { of visual images }\end{array}$ & $\begin{array}{l}\text { Collecting data } \\
\text { - observation or } \\
\text { reconstructing of the } \\
\text { act of visual image } \\
\text { presentation }\end{array}$ & $\begin{array}{l}\text { Possible } \\
\text { transcription of } \\
\text { data }\end{array}$ & $\begin{array}{l}\text { Analysis of the } \\
\text { inner with the } \\
\text { "outer context } \\
\text { of image" }\end{array}$ \\
\hline $\begin{array}{l}\text { C. Visual product } \\
\text { and its content }\end{array}$ & Preserving the images & $\begin{array}{l}\text { Replicative } \\
\text { transcription of } \\
\text { pictures, images } \\
\text { (necessary at } \\
\text { the beginning } \\
\text { of research and } \\
\text { voluntary in } \\
\text { later phases of } \\
\text { analysis) }\end{array}$ & $\begin{array}{l}\text { Coding } \\
\text { the textual } \\
\text { replication of } \\
\text { visual data or } \\
\text { coding visual } \\
\text { data without } \\
\text { transcription }\end{array}$ \\
\hline $\begin{array}{l}\text { D. Reception of } \\
\text { the visual objects } \\
\text { and images by } \\
\text { others and by } \\
\text { their creator }\end{array}$ & $\begin{array}{l}\text { Collecting data - } \\
\text { observation and } \\
\text { eliciting the data on } \\
\text { reception of objects } \\
\text { by interviews, } \\
\text { questionnaires, extant } \\
\text { data, or by historical } \\
\text { reconstruction }\end{array}$ & $\begin{array}{l}\text { Transcription of } \\
\text { data }\end{array}$ & $\begin{array}{l}\text { Analysis of } \\
\text { "the outer } \\
\text { context of } \\
\text { image", visual } \\
\text { cultures and } \\
\text { subcultures/ } \\
\text { social worlds }\end{array}$ \\
\hline
\end{tabular}

The inner context of image ("how" it was created) is connected with the outer context of image ("how" it will be perceived). The outer context includes stylistic conventions and clues to visual presentations (visual cultures and subcultures; Pink, 2007: 31-33). The pictures are embedded in the social and cultural conventions of representing social objects (Banks, 2007). Many of these conventions clash or compete among themselves in the same image or in an act of imagining. 
Researchers in visual studies usually concentrate on one or a few slices. The visual product has a privileged position once it is officially labelled as "the" image that we want to describe and analyse. We look for the theoretical implications that go beyond the picture very often - albeit often ignorant about the contexts of its creation and reception. Usually, we have access to one or two slices of data, the product itself and its reception. The sociological approach supported by the ethnographic strategy of research extends the perspective of perception to acts of creation and reception of an image, accounting for the contextual embeddings of images. ${ }^{4}$

A. The act of creation. Research procedures should be adjusted if we intend to acquire slices of data. An act of creation of image (whether it is created by investigated subjects or by a researcher) needs to be observed and described by a researcher. Detecting motives and cooperation strategies could help explain why and how the actors build visual worlds (cf. Becker, 1982). We need direct access to the context of creation. The observation method could be the best way to get information, together with interviewing and audio-visual registration of interaction and actions (Schubert, 2006). Recorded data should subsequently be transcribed and analysed - focusing on inner context: interactions, actions, cooperative project work, nonverbal communication, gestures, coordination of moves, etc. Transcription is optional. If we are mainly interested in the creation slice of visual processes, we can do transcription very scrupulously, also concentrating on the detailed exchange of interactional moves and dynamics of conversation if relevant (Schubert, 2006). If not, we can stick to observational notes or direct recordings describing the context of creation.

B. Participation in demonstrating/communicating visual images. Research procedures are, as in the action-"slice" above, focused on observing acts of demonstrating/communicating/representing created images. Transcription of data is optional, we can write a memo directly from observation; everything depends on our goals and on the varieties of visual processes to be studied. Although creation is often accompanied by demonstration/communication, we single it out. This slice of imagining helps focus on the emergent structure of social communications as a process. If we cannot reconstruct these acts by ethnographic methods, we should

\footnotetext{
${ }^{4}$ Although the perspective of the cultural studies could be used here (Griswold, 2008: 73-97), we are opting in the direction of interactionist sociology. We are also interested in the production, distribution and reception of cultural objects but mainly in the problem: how are these elements elaborated for interactional partners? We analyse how the images and visual processes are constructed hic et nunc in the context of the co-presence of interactants and/or how the space and time is ordered for future encounters. The meaning of cultural objects is created, according to our perspective, in the interaction.
} 
reconstruct them in any available way (e.g. by historical methods, comparative analogy, deduction based on the empirical evidence and testimony provided by experts, etc.).

C. The visual product and its content. A visual product should be recorded: described and/or drawn, photographed and/or video recorded and saved as a digital file for later analysis and presentations. Once in the possession of the image, we should perform "replicative transcription". First, we should describe pictures that we want to analyse in detail. We need such transcription to extract from the picture every detail that could be salient in later analysis. Transcription (the verbal description of a picture) sensitizes us to details and helps us to search for structural aspects (Konecki, 2009: 75-76; see also Photo 1 and Table 2 below). Later on, having chosen categories and properties for elaborating, we can code other pictures directly - and without transcription. This slice of data prepares us for coding the textual replication of data, if available. Later, we code visual images directly - having already chosen core and auxiliary categories for fuller elaboration of their properties and connections with other categories and properties (selective coding).

D. Reception of the visual objects and images by others and by their creator. Pictures, visual physical artefacts and body gestures are created, intentionally or not, for audiences. The reception of visual images is a very important slice of imagining. Such reception can be researched by observing and/or eliciting data. Interviews and questionnaires can induce them. The extant data, if available, can also be used for the coding. This slice is also connected with the reconstruction of the aesthetic, social and broad cultural conventions among the factual and potential recipients (audiences). Coding this outer context is essential to meet the requirements of grounded theory, to generate broader understanding of the visual image creation, presentation, content and contextual reception in a given culture, subculture or social world.

\section{Constructing categories}

Categories are constructed when researchers start coding images and contexts of their creation, reception and display.

We start from open coding. Open coding is a procedure of labelling parts of the transcribed text to move analysts' mode of thinking from the level of concrete description to the conceptual level. We code four slices of data to understand better contexts and actions/interactions, image/visual artefacts displays and contents of visual artefacts. Open coding creates a theoretical space for thinking and prepares us to look for the first indicators of categories that could be interesting for further elaboration and creation of theoretical state- 
ments. Data tend to be mainly textual, but we can also code images directly. At the beginning of research and analysis, we transcribe/describe images to get into the details of the phenomenon's visual sphere (see also Suchar, 1997; compare Strauss, 1987: 30-32; Strauss and Corbin, 1990: 61).

After description, we should write a memo on the images themselves and on the contexts of their production, in order to find deeper meanings of their visual aspects.

Let us examine a case in point. Below is a transcription of an image and an open coding case (Table 1). The data come from our research project on "the visualization of hatha yoga practice". The transcriptions and memos have been made by the researcher who has had inner knowledge of the social world. He has practiced yoga and studied thoroughly the principles of hatha yoga. The visualization of yoga practice is taking place in many contexts. The process of visualization of yoga practice has many dimensions. The most outer dimension is connected with presenting body movements according to strict rules. Yoga masters established these rules and there is an internal imperative to implement them in practice. The rules are about coordination of many movements, so the complexity of the correct yoga pose performance is very high. Another dimension is connected to experiencing bodies and minds during the actual exercise. Communicating it to outsiders is very difficult. Practitioners usually simply show the poses to interested audiences, instead of verbal explanation of the lived experience (see Photo 1).

Photo 1. The slice of visual product and its content. Private visualization of yoga practice. Hatha yoga practice at home (photo from our research project)

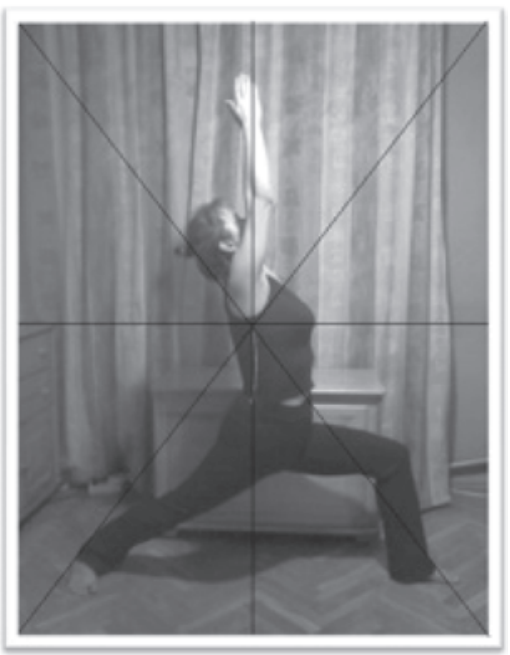


The slice of the photo creation.

The woman in the photo preferred to show a pose rather than to explain it. The lines on the photograph help in exact description of images and in localization of objects. Moreover, they help evaluate technical aspects of the photography (focusing, etc).

Table 2. The practice of hatha yoga at home (private context); the spatial context of practice

\begin{tabular}{rll}
\hline No & Description of the picture & Open codes \\
\hline 1 & In the picture we see a women practicing & Practicing yoga, practitioner's gender \\
2 & yoga. She stands in "The Warrior" pose. & Name of the pose, knowledge of yoga \\
3 & The woman is practicing yoga in her own & Location and space of practice \\
4 & apartment. We can see the parquet floor, & Physical surroundings of the practice \\
5 & on which she stands. She is barefooted & Visibility of the body; outfit \\
6 & and wears a tracksuit. She steps forward & Position of legs \\
7 & with the left foot, bending her knee & Parameters of the positions \\
8 & almost at the right angle. The foot points & Parameters of the positions of both legs \\
9 & forward. The right foot is planted behind & Parameters of the position of each leg \\
10 & her, so that the right leg runs at a 45 & Parameters of the positions of heels \\
11 & degree angle above the floor. The heels & Parameters of the positions of different \\
12 & are in line. The navel area is pulled up. & body parts \\
13 & She raises her arms and stretches them & Positions of body parts in relation to one \\
14 & and her hands above her head. Palms are & another; the name of the sub-positions \\
15 & locked in the prayer position. Her face is & Positions of shoulders \\
16 & slightly lifted following her hands. Some & Positions of head \\
17 & furniture can be seen; a night table, in & The spatial context of practice \\
18 & the background, and a curtain (probably & Furniture \\
19 & covering a window). A bedside table to & Spatial locations of visible furniture \\
20 & the left. Cables are plugged to an electrical & Spatial context of practice \\
21 & outlet on the floor (lower left) and a pipe & Spatial locations of physical artefacts \\
22 & of the radiator is visible above it. & List of visible physical artefacts \\
\hline
\end{tabular}

\section{Memos on photo 1}

\section{Inner context}

The photograph presents the process of practicing yoga in a private context (the practitioner's private apartment). The researcher asked her to show what she felt during practice. The practitioner explained verbally and demonstrated details of her practice in front of a camera. The resulting photograph supplied the most important part of her explanation of yoga practice.

\section{Display of practice}

The practitioner arranged her place for a demonstration of the practice and picture-taking. She took off her socks and put on a tracksuit. The prac- 
titioner drew a curtain covering her window and prepared an empty space for her demonstration and photographic record.

\section{Interpretation of the picture's content}

Looking at the picture and acquainted with the context, we know that hatha yoga can be practiced in a private space (in an apartment or in a house). Space is limited, which may constrain practice, although it seems sufficient to exercise at least some yoga poses. Thus one can practice yoga without major problems in most available places (other pictures confirm this conclusion) in diverse physical surroundings (see Photographs 3 and 4).

Both description and the photographs demonstrate that parameters of the body part positions are significant: what matters is shaping and "sculpturing" one's body in a given space for a given moment. The body looks intentionally sculptured, an assumed pose is maintained for a while; the photograph freezes it "forever". "Surrounding space seems to be sculptured by the body." The pose redefines the surrounding space, it is not a bedroom anymore, it becomes a yoga exercise ground. The meaning of space changes following an activity performed in this space.

\section{Interpretation of the outer context of the picture - reception}

The description of body movements suggests that the describer/transcriber is a competent yoga observer, and has at least basic knowledge of yoga practice (he knows the names of different poses), being aware of the necessity to coordinate movements of body parts. This coordination is achieved by applying rules established by masters of hatha yoga practice and communicated during training sessions, which socialize practitioners. To put it in a nutshell: in order to understand both a demonstration and a picture at first glance, an observer must possess at least minimal expert knowledge about this practice. This awareness on the part of the researcher is crucial, because practitioners often refer to their body experience linked to yoga exercises.

The focus of the picture is at the chest level. A photographer wanted to catch the symmetry of the pose and to show a complete position. By drawing the diagonal, horizontal and vertical lines we can locate the focus of the picture and understand the intention of the photographer trying to catch the symmetry of the body pose.

We write a memo in order better to understand a given situation and relevant contexts of the investigated activities. The description of the pictures and memos provides us with a deeper insight into the situation composed of interactions, actions and life worlds (see also Konecki, 2009: 75). 
Adele Clarke suggests writing so called "specification memos", which help "to break the frame, so we can 'see' an image in multiple ways" (2005: 226-227). The function of our reconstruction of multislice imagining is similar to A. Clarke's "breaking the frame". But our approach goes further. We also see multislice imagining as an instrument for theoretical saturation, for creating the theory. The above analysis of a photograph is a case in point. It provides an example of saturating the category of the yoga practice visualization, with diverse possible spatial contexts (and patterns) of acting and interacting with the audience accounted for - in order to create more complete, integrated generalizations.

We do not merely describe a situation. We do not want to concentrate mainly on the context and only to specify it. Multislice imagining is not situational analysis; it is only a tool to adjust the mind of the researcher in connecting any specific features of the events with generic processes that should be theoretically elaborated. Moreover, there are avoided assumptions on the content of the situations and events in a context. Multislice imagining is only "the grammar of narratives" (cf. Tavory and Timmermans, 2009: 255) that frame observed cases during an investigation. The ethnographic observations and/or visual descriptions here are not tied to external forces, "social laws" or patterns of domination or oppressions. The theoretical patterns are looked for in the data and are constructed by meticulous analysis.

Ethnography itself could be used to focus mainly on processes that are internal to the situation or to combine it with theory of external social forces to explain what is going on hic et nunc. However the ethnography is not GTM. ${ }^{5}$

\section{Selective coding}

After open coding and writing memos on the codes and coded images, a researcher has to decide which category should be theoretically elaborated (it could become a core category in a future theoretical scheme). Should we select the category "visualization of yoga practice", we have to reconstruct it, to learn "how" this yoga practice is visually organized. The practice in-

\footnotetext{
${ }^{5}$ The ethnographic research and data analysis of Clarke $(2005,2006)$ and Burawoy $(1998$, 2000) are paradoxically very similar in terms of looking for the external forces to explain the investigated situations. They both presuppose certain theoretical assumptions that structure their substantive research. For Burawoy there are social forces connected with economic and political domination or hegemony (neo-Marxist theoretical framework): for Clarke there are oppressive forces that come from the social structure of modernistically patterned society, where the minorities do not have a voice and their own gaze (feminist and postmodern social theories). Burawoy and Clarke use the external theory to organize their explanations of the ethnographically investigated situations.
} 
volves more than verbal instruction and body experiences, we have to trace the entire organization of visual images and visual practices that accompany the action and prepare its reception (also in outer context). In order to be socially approved, a concrete practice should be displayed. It should be visually pervasive - a viewer must be able to identify it as this concrete action of yoga practice and not another one. Visual images have a stable meaning and are generated by a practitioner as part of the exercising activity. They are organized according to the rules and values of a particular social world.

What does the visual organization of an activity mean? The process of a construction of visual phenomenon begins with coordination work accompanied by systematic perception/interpretation of the constructed action. It continues with accounts of diverse indispensable aspects of creation, reception, and maintenance of the phenomenon in question. Activities often tend to be visually maintained. "To see” very often means "to be”. The visualisation processes are social processes and should be analysed as basic social processes. Many basic social processes are entangled with one another and intertwined. For instance, a visualisation of the social ritual of enhancement could be simultaneously construed as the visual construction of competition, or a process of yoga practice visualisation is connected with the process of becoming yoga practitioner.

Having chosen the core category, we immediately start writing theoretical memos with a more profound awareness of their methodological implications (see Appendix 1). We perform selective coding. We elaborate basic visual processes using theoretical codes, always aware of empirical context.

If we want to write a memo on the process of visualization of yoga practice by concentrating on the property "transmission of knowledge about yoga practice", we can write it relying on comparative work concerning the commercial and professional video presentations of yoga instructions (see and compare professional presentation http://www.youtube.com/watch? $\mathrm{v}=2 \mathrm{uf} 2 \mathrm{yTj} 2 \mathrm{kK} 4 \&$ feature=related with natural ones http://www.youtube. com/watch?v=ppPPtcpv0kI, http://www.youtube.com/watch?v=M5SwU-de3 $\mathrm{X} 8 \& N R=1$; see the Theoretical Memo on Transmission of Embodied Knowledge in Appendix 1).

\subsection{Comparative analysis of images}

Visual grounded theory is based primarily on the comparative method. Comparing the images is a very robust way to generate theoretical codes or relations of codes (see Suchar, 1997).

Using pictures and sequencing of pictures, which give a comparative insight into empirical data (on comparative analysis see Glaser and 
Strauss, 1967), we are making use of an important methodological instrument. Some of the sequences record stages of action. These are natural sequences. Analysis of a sequence of pictures helps us to recognize patterns, thus contributing to the conceptual understanding of the phenomena under investigation (Konecki, 2009: 89).

We can compare artificial sets of the diverse displays of actions or objects and analytically elaborate them (see the example in Konecki, 2009: 68-74). If we compare the photos of homeless people taken by themselves - we can detect their visual perspective, "the way they see themselves and their life". Visual "contrasting work" allows us to notice and record distinctions between "normals" and homeless in real life situations. We can observe that these two kinds of human categories occupy different public spaces, look different, and are separated in interactional space. We notice in these photographs the contrast of wealth and poverty on two different planes, etc. (Konecki, 2009: 70-71). These contrasts also create the pattern of the visual organization of perception of the world by homeless photographers.

We should always know what had happened before a picture was taken, as well as what continued to happen afterwards in natural sequences; this resembles analysis of sequences in textual data (Silverman, 2007: 61-84, 146). The analysis of gestures can be very important in understanding the organization of action.

We can juxtapose the pictures of yoga practice in different contexts, for example at home (Photo1), in a training hall (Photo 2), in a park (Photo 3 and 4).

\section{Photo 2. Spatial contexts of yoga practice: training hall}

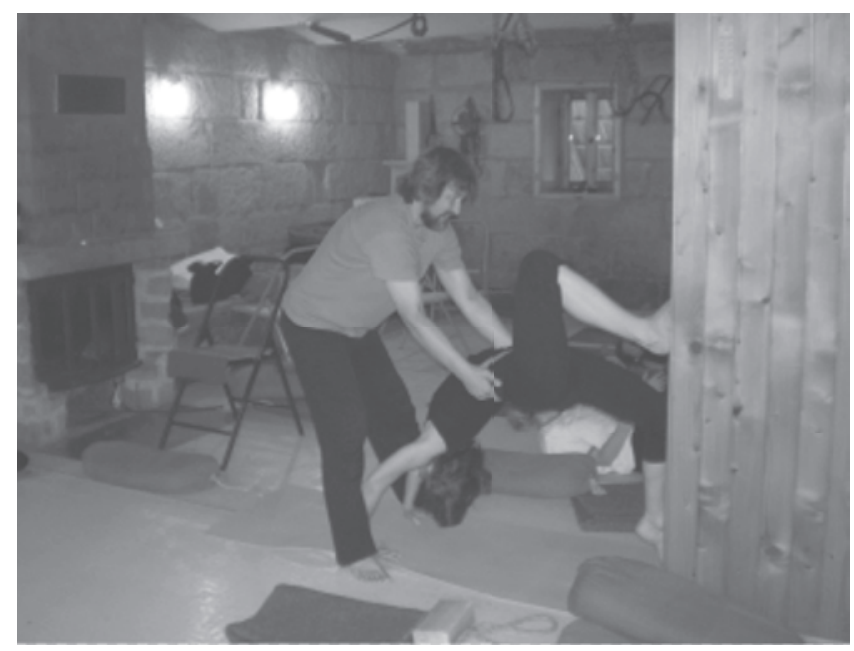


The modified wheel pose (urdhva dhanurasana - Upward Bow Pose). Help from the instructor; direct correction of the body position by the instructor. Instructor touches a practitioner.

Photo 3 and 4. Spatial context of yoga practice: yoga in a park

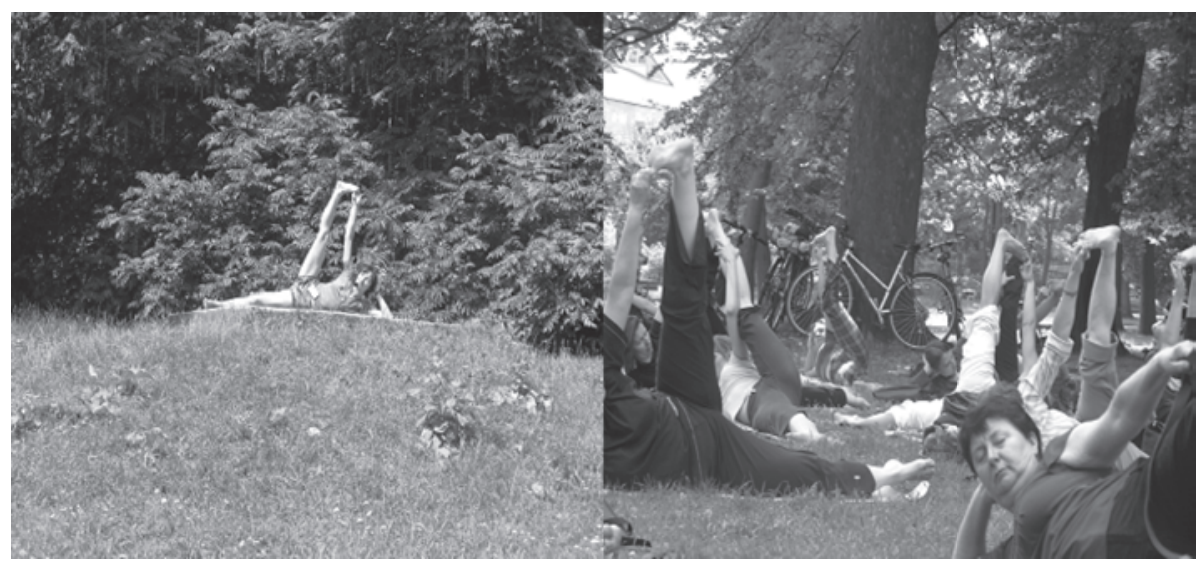

Instructor demonstrates the pose on the hill. Participants follow the instructor (see Comparative Theoretical Memo in Appendix 1).

\section{Theoretical sampling}

Theoretical sampling answers the researcher's questions generated by the analysis of empirical data. Writing theoretical memos, we become more aware of the direction of the research and analysis. Theoretical sampling is an iterative process of analysis and data gathering. We do not want to sample just for showing the distribution of the phenomenon in the population. The initial sampling is necessary to start research and the researcher should select criteria for choosing empirical data: places, structures, groups, physical artefacts, etc. However, it is not the sampling itself that has a theoretical character. The theoretical sampling emerges later during the analysis while coding and writing memos (Charmaz, 2006: Ch. 5), although we should remember that the theoretical sampling occurs all the time together with data collecting, coding and theoretical memos writing.

Theoretical sampling helps in saturating the category by helping us to detect data, indicating conceptual properties of the category. Thus theoretical sampling is connected with saturating the category.

Let us take the example of research about the process of visualization of homelessness and let us analyse the subcategory of the process, namely the visualisation of physical conditions of a homeless life world. We 
look for the places and contexts, which could help us saturate the category and theoretically elaborate it. Beginning research with sampling limited to visual data from shelter contexts, we have noticed many aspects of their living conditions: "being confined in limited space", focus on food, lack of privacy, bedding. While analysing these data, we realized that the space of homelessness is institutionally organized and there is no private sphere left. Even when analysing the context of taking pictures, we noticed the problem of keeping enough distance to set and focus a camera to take a photo of the homeless or objects surrounding them. The theoretical questions are:

- How is the homeless space socially organized?

- How is the homeless space organized outside a shelter, in different contexts?

- What kind of social actors organize it for them?

- What are the relations between these actors?

- How is public space organized for visualizing purposes?

When collecting data outside of shelters, we have noticed that the physical conditions of life may differ, but emerging patterns are the same. The visibility of the homeless is organized in order to keep them outside of the mainstream activities in public places. They do the dustbin work very often at night - to keep themselves invisible. They travel by public transport at night to remain invisible during the day. They look for ruins, sheds and other places for living, far from public scrutiny and to avoid becoming visible. The visual dimension of homelessness is paradoxically often arranged both by the homeless themselves and by public onlookers. Both try to make the homeless invisible (Konecki, 2009).

Comparing data when analysing generates theoretical hints. The code of "bedding" generated by observing the behaviour of the homeless at the shelters is parallel to sitting on street kerbs ("kerbing”). We can create a theoretical code on a higher level of abstraction and say that these two kinds of activities constitute properties in a "killing time" category (which creates a "waiting" atmosphere for homeless people). The category could not be generated if we did not have these visual data (Konecki, 2009: 80).

Theoretical sampling for visual processes requires us to become aware of "methods of taking pictures" and of the "contexts of their production". We are interested in the first, second and third slice of imagining. So we sample by collecting images, and contexts (inner and outer), and sample perspectives of seeing the events and actions (e.g. photos of homeless taken by homeless, by journalists, artists, scientists, etc). If we look for the ar- 
tistic visions of the homeless, we notice some kind of aesthetisation of homelessness together with a tendency to exhibit photographs according to stereotypes of the homeless individuals. Homeless people are expected to go begging, to be sick, to eat food of very low quality, they loiter around the city, they live in the wealthy society around them and "normals" do not have empathy with them, they are visible to the public, etc. (see the movie on a homeless man "My Name is Jarek", http://su8.pl/jarek/, and Appendix 2, Theoretical Sampling).

The basic visual process is elaborated here more thoroughly by theoretical sampling of the places, groups, communities, and physical artefacts that could deliver the new or, expectable from the logical elaboration of data gathered earlier, general aspects of categories.

Theoretical saturation is a parallel procedure, accompanying theoretical sampling and following it. Saturation is achieved by using visual data in elaborating theoretically visual processes (see Appendix 3 and Diagram 1 with theoretical explanations).

\section{Conclusions and future prospects}

The multislice imagining helps to organize the meticulous analysis of visual data. It structures the research process and allows for the development of abstract features of categories. We have tried to show how constructing of categories goes on during the visual data analysis by using GTM. The researcher situation and the context of images production are important in the analysis. However, that does not mean that GTM is mainly based on ethnographic endeavour. The context can be reconstructed by historical analysis or by analogical analysis, when we look for the data on the context of image production in some analogical situations. Distribution of image and/or visual presentation is easier to follow if we look for the reconstruction of visual processes. Generally the researchers concentrate on the analysis of the content of the image. Although it is a very important slice of the imagining, it is not enough to elaborate the social process of visualization. The dimension of production, demonstrating and reception of the image/picture should also be analysed and taken into consideration in the constructing of theoretical hypotheses.

We have presented the procedures of GTM in the visual data analysis: open coding, memo writing, selective coding, theoretical memo writing, comparative analysis and theoretical sampling. These all belong to the classical tool kit of the GT researcher and analyst. However, we should bear in mind the structure of multislice imagining when we use them. Theoretical sampling should be concentrated on slices that we described in the multi- 
slice imagining model. The same applies to constant comparative analysis methods.

We believe that visual grounded theory as the methodology of social sciences deserves to grow and develop. The main reason is the "the visual turn", which has emerged in our times. We have to deal with increasingly numerous visual artefacts and visual processes in our everyday life (Emmison and Smith, 2000). We create Power Point presentations, where "speech transforms into presentations" (Knoblauch, 2008), we take photographic pictures and present our experiences to our families and friends by showing photographs and video recordings (Walker and Kimball Moulton, 1989), we send pictures by mobile phones to testify about our current location, we observe advertisements in TV and create photo blogs and video blogs on the internet (Cohen, 2005), etc.

Visual data open new possibilities to develop grounded theories. Developing of theories of substantive visual processes could facilitate constructing formal theories of the visualization of social problems, visualization of organizational politics, visualization of identity, etc. The most ambitious goal looms large on a theoretical horizon: the construction of a formal theory of the visualisation of action. The future of grounded theories will inevitably be associated with constructing theory on the social, cultural and psychological dimensions of visual reality, not only because of our societies' recent "visual turn", but also because of the growing research focus on the visuality of our social worlds.

\section{REFERENCES}

Banks, Marcus (2007). Using Visual Data in Qualitative Research. Los Angeles: Sage.

Becker, Howard S. (1982). Art Worlds. Berkeley: University of California Press.

Bryant, Antony (2009). "Grounded Theory and Pragmatism: The Curious Case of Anselm Strauss", Forum Qualitative Sozialforschung / Forum: Qualitative Social Research, 10 (3), Art. 2 [113 paragraphs], http://nbn-resolving.de/ urn:nbn:de:0114-fqs090325.

Burawoy, Michael (1998). "The Extended Case Method”, Sociological Theory, 16 (1): 4-33. doi:10.1111/0735-2751.00040

Burawoy, Michael et al. (2000). Global Ethnography: Forces, Connections, and Imaginations in a Postmodern World. Berkeley: University of California Press.

Byczkowska, Dominika (2009). "What do we study studying body? Researcher's attempts to embodiment research", Qualitative Sociology Review, 5 (3): 100112, http://www.qualitativesociologyreview.org/ENG/Volume14/QSR_5_3_Byczkowska.pdf. 
Charmaz, Kathy (2006). Constructing Grounded Theory: A Practical Guide through Qualitative Analysis. London: Sage.

Clarke, Adele E. (2005). Situational Analysis: Grounded Theory after the Postmodern Turn. Thousand Oaks, Ca: Sage.

Clarke, Adele E. (2006). "Feminisms, Grounded Theory, and Situational Analysis", in: Sharlene Nagy Hesse-Biber (ed.). Handbook of Feminist Research: Theory and Praxis. Thousand Oaks, CA: Sage, pp. 345-370.

Cohen, Kris R. (2005). "What Does the Photoblog Want?", Media, Culture \& Society, 27 (6): 883-901. doi:10.1177/0163443705057675

Emmison, Michael and Smith, Philip (2000). Researching the Visual: Images, Objects, Contexts and Interactions in Social and Cultural Inquiry. London: Sage.

Glaser, Barney G. (1978). Theoretical Sensitivity: Advances in the Methodology of Grounded Theory. Mill Valley, Ca.: Sociology Press.

Glaser, Barney G. (2002). “Constructivist Grounded Theory?”. Forum Qualitative Sozialforschung / Forum: Qualitative Social Research, 3 (3), Art. 12 [47 paragraphs], http://www.qualitative-research.net/index.php/fqs/article/view/825.

Glaser, Barney G. (2004). "Naturalist Inquiry and Grounded Theory", Forum Qualitative Sozialforschung / Forum: Qualitative Social Research, 5 (1), Art. 7 [68 paragraphs], http://nbn-resolving.de/urn:nbn:de:0114-fqs040170.

Glaser, Barney G. and Strauss, Anselm L. (1967). The Discovery of Grounded Theory: Strategies for Qualitative Research. Chicago: Aldine.

Griswold, Wendy (2008). Cultures and Societies in a Changing World. 3rd ed. Los Angeles: Pine Forge Press.

Goode, David (2007). Playing With My Dog Katie: An Ethnomethodological Study of Dog-Human Interaction. West Lafayette, Ind.: Purdue University Press.

Heath, Christian and Luff, Paul (2007a). "Ordering competition: the interactional accomplishment of the sale of art and antiques at auction", The British Journal of Sociology, 58 (1): 63-85. doi:10.1111/j.1468-4446.2007.00139.x

Heath, Christian and Luff, Paul (2007b). "Gesture and institutional interaction: figuring bids in auctions of fine art and antiques", Gesture, 7 (2): 215-240. doi:10.1075/gest.7.2.05hea

Katz, Jack (1999). How Emotions Work. Chicago: University of Chicago Press.

Kelle, Udo (2005). “'Emergence' vs. 'Forcing' of Empirical Data? A Crucial Problem of 'Grounded Theory' Reconsidered”, Forum Qualitative Sozialforschung / Forum: Qualitative Social Research, 6 (2), Art. 27 [52 paragraphs], http:// www.qualitative-research.net/fqs-texte/2-05/05-2-27-e.htm.

Knoblauch, Hubert (2008). "The Performance of Knowledge: Pointing and Knowledge in Powerpoint Presentations", Cultural Sociology, 2 (1): 75-97. doi:10.1177/1749975507086275

Konecki, Krzysztof Tomasz (2008a). "Touching and Gesture Exchange as an Element of Emotional Bond Construction. Application of Visual Sociology in the Research on Interaction between Humans and Animals", Forum Qualitative Sozialforschung / Forum: Qualitative Social Research, 9 (3), Art. 33 [93 paragraphs], http://nbn-resolving.de/urn:nbn:de:0114-fqs0803337. 
Konecki, Krzysztof Tomasz (2008b) "Grounded Theory and Serendipity. Natural History of a Research", Qualitative Sociology Review, 4 (1): 171-188, http:// www.qualitativesociologyreview.org/ENG/Volume9/QSR_4_1_Konecki.pdf.

Konecki, Krzysztof (2009). "Teaching Visual Grounded Theory”, Qualitative Sociology Review, 5 (3): 64-92, http://www.qualitativesociologyreview.org/ENG/ Volume14/QSR_5_3_Konecki.pdf.

Pink, Sarah (2007). Doing Visual Ethnography: Images, Media and Representation in Research. 2nd ed. London: Sage.

Puddephatt, Antony J. (2006). "An Interview with Kathy Charmaz: On Constructing Grounded Theory", Qualitative Sociology Review, 2 (3): 5-20, http://www. qualitativesociologyreview.org/ENG/Volume5/QSR_2_3_Interview.pdf.

Reichertz, Jo (2010). "Abduction: The Logic of Discovery of Grounded Theory", Forum Qualitative Sozialforschung / Forum: Qualitative Social Research, 11 (1), Art. 13 [39 paragraphs], http://nbn-resolving.de/urn:nbn:de:0114-fqs1001135.

Schubert, Cornelius (2006). "Video Analysis of Practice and Practice of Video Analysis: Selecting field and focus in videography", in: Hubert Knoblauch, Bernt Schnettler, Jürgen Raab and Hans-Georg Soeffner (eds). Video-Analysis. Methodology and Methods: Qualitative Audiovisual Data Analysis in Sociology. Frankfurt am Main: Peter Lang, pp. 115-126.

Silverman, David (2007). A Very Short, Fairly Interesting and Reasonably Cheap Book about Qualitative Research. London: Sage.

Strauss, Anselm (1976 [1961]). Images of the American City. New Brunswick, N. J.: Transaction Books.

Strauss, Anselm L. (1978). "A social world perspective", in: Norman K. Denzin (ed.). Studies in Symbolic Interaction. Vol. 1. Greenwich, CT: JAI Press, pp. 119-128.

Strauss, Anselm L. (1987). Qualitative Analysis for Social Scientists. Cambridge: Cambridge University Press.

Strauss, Anselm and Corbin, Juliet (1990). Basics of Qualitative Research: Grounded Theory Procedures and Techniques. London: Sage.

Strübing, Jörg (2004). Grounded Theory: Zur sozialtheoretischen und epistemologischen Fundierung des Verfahrens der empirisch begründeten Theoriebildung (Qualitative Sozialforschung Bd. 15). Wiesbaden: VS Verlag für Sozialwissenschaften.

Strübing, Jörg (2007). Anselm Strauss. Konstanz: Uvk.

Suchar, Charles S. (1997). "Grounding Visual Sociology Research in Shooting Scripts", Qualitative Sociology, 20 (1): 33-55. doi:10.1023/A:1024712230783

Tavory, Iddo and Timmermans, Stefan (2009). "Two cases of ethnography: Grounded theory and the extended case method", Ethnography, 10 (3): 243263. doi:10.1177/1466138109339042

Walker, Andrew L. and Kimball Moulton, Rosalind (1989). "Photo Albums: Images of Time and Reflections of Self”, Qualitative Sociology, 12 (2): 155-182. doi:10.1007/BF00988996 


\section{APPENDIX 1}

\section{Theoretical memo on transmission of embodied knowledge}

(from comparative analysis of professional presentation of yoga practice http://www. youtube.com/watch? $\mathrm{v}=2 \mathrm{uf} 2 \mathrm{yTj} 2 \mathrm{kK} 4 \&$ feature=related and natural ones http://www. youtube.com/watch?v=ppPPtcpv0kI, http://www.youtube.com/watch?v=M5SwU-de3 $\mathrm{X} 8 \& \mathrm{NR}=1$ )

The transmission of embodied knowledge by video visualization with the help of verbal description shows us only a surface layer of embodied knowledge. In professional presentations we find little evidence of the transfer of knowledge on experiencing one's body, or about feelings and emotions. Only in natural presentations we can find references to body feelings, although not frequently. Actual transfer happens during real exercise lessons, when instructors very often point some feelings out and interpret them (e.g. "nice feeling resulting from stretching", "it's a great fun between the transition from lying on the floor to standing up or from standing up to the floor"). They try to increase their students' understanding of body in relation to space ("feel the space in your body").

There is a difference between presentations of visual instructions in a professional video and in a natural situation. Visualizations of transmission of embodied knowledge depend on the mode of presentations: instructors can be using technical aids (e.g. video movies) or actual, real-life demonstrations. (memos from the author research on yoga practice)

\section{Comparative theoretical memo}

Comparing photographs 1, 2, 3 and 4 (in the original text of the paper) we notice different spatial contexts influencing the visualisations of yoga practice.

Yoga practice is visualized as requested by a researcher in picture 1 , other pictures $(2,3,4)$ were taken without a formal request to demonstrate yoga practice. Picture 1 differs from the others on the visual level in a fundamental way. Yoga at home is done alone. There is no instructor to help or correct the pose and to give advice. A body has to be shaped and presented correctly by performer herself. She is the only spectator, and she perceives her body pose mainly by experiencing it. Sometimes household member can observe the practice, or some outsider (a researcher of yoga practice had often seen it happen).

Practicing yoga at a training hall we can receive instructions from a teacher and be corrected by his/her touching of our body. Other yoga practitioners can also observe us at that time. The practice is individual but visible to other performers in the group. Presenting an individual in yoga poses is often encountered in photographic visualizations of yoga practice (e.g. in the yoga posters), but actual practice usually involves group exercise, with participants visible to one another.

This group aspect is clearly visible in the "yoga in the park" pictures. Following visual clues, we can trace practitioners imitating their teacher. She shows the pose and practitioners follow her. The park is a public and open space. Bystanders can observe the practice and even take a picture, which sometimes actually happens. 
Comparing spatial contexts we notice that audiences changes from a single individual practitioner at home context to the possible group of observers at the training hall, and to a broader group of practitioners, instructor and bystanders able to observe exercises in the park. Bystanders could be random and anonymous or familiar to practitioners.

The spatial aspects of the yoga practice organize the visualization process of yoga practice in different ways. Spatiality is connected to the degree of visibility of the practice to others. Yoga practice is not only individual, as frequently assumed. It is socially organized in spaces - more or less open to potential audiences. Visualization of the practice is then regulated by socially defined space for actions. Photo or video recordings could preserve the visualization of the practice for others. So the process of visualization could reach a broader context by publication of it in the mass media or on the Internet.

\section{APPENDIX 2}

\section{Theoretical sampling}

In the social advertisements for movies on homelessness, we can observe verbal emotional appeals and their visualization, as for example, visualization of cold weather and death.

Photo 1. Aesthetization. Public advertisements. Verbal emotional appeal and visualization of cold weather outside, and of death

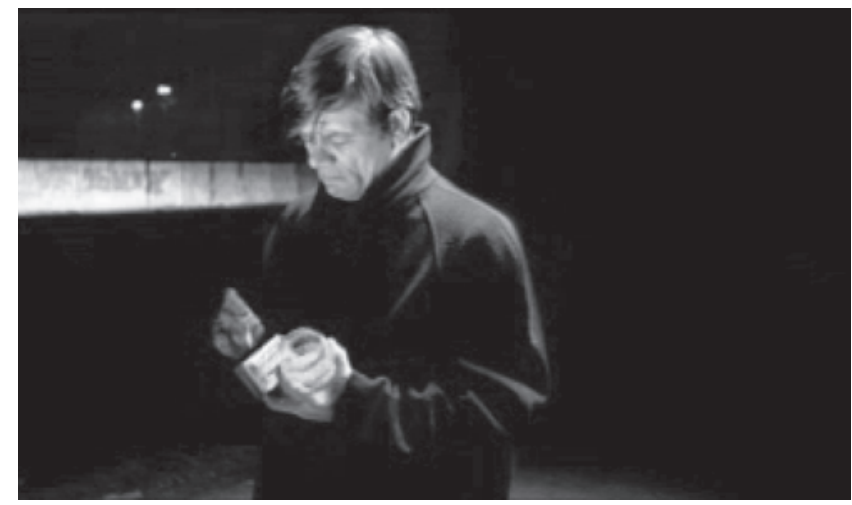

The character in the movie appears against the background of a bridge and a river. He says: "The last winter 250 people froze to death. (He lights the candle.) www.bezdomni.pl is the only address I have. (Darkness, candles in the background under the pillar of the bridge.) Help homeless people" (the text transcription and the snapshot from the public advertisement video http://www.bezdomni.pl/movies/ bezdomni15.mpg).

The sampling of artistic perspective allowed us theoretically to elaborate not only the properties of homeless visual views but also external, "artistic" views 
that shape the stereotypical attitudes and visual imaginations of homelessness in a society (see Table 1 below).

Table 1. Contrasting two visual perspectives of homelessness: homeless individuals' view versus a publicly endorsed "aesthetic" view

\begin{tabular}{|l|l|}
\hline $\begin{array}{l}\text { Homeless visual view } \\
\text { Focus on everyday life } \\
\text { Practical approach }\end{array}$ & $\begin{array}{l}\text { External aesthetic view } \\
\text { Focus on problematic situations } \\
\text { Stereotypes }\end{array}$ \\
\hline Confined space, lack of privacy & Illness \\
\hline Street work (collecting things) & Begging and emotional appeals \\
\hline Invisibility (covering up, shame) & Visibility (for presentation of a problem) \\
\hline $\begin{array}{l}\text { "Killing time" (bedding, benching, } \\
\text { kerbing, walking) }\end{array}$ & Suffering and death (emotional appeals) \\
\hline $\begin{array}{l}\text { Mainly "visual - present - time } \\
\text { perspective" is presented }\end{array}$ & $\begin{array}{l}\text { Possibility of an escape from } \\
\text { homelessness, future perspective }\end{array}$ \\
\hline $\begin{array}{l}\text { Focus on food } \\
\text { Contrasting naturally "natural } \\
\text { differences" }\end{array}$ & $\begin{array}{l}\text { Focus on food } \\
\text { appeals }\end{array}$ \\
\hline
\end{tabular}

An excerpt from a theoretical note demonstrates consequences of theoretical sampling. The sampling furnishes the base for developing the general statements:

Table 1 demonstrates that presented visual perspectives of homelessness are completely different, and have only two aspects in common: a focus on food and contrasting the lifestyle and wealth level between "normals" and homeless people. The visualization process of homelessness is internally divided. The set of pictures and subsequent visual images are constructed visual arenas where the discrepancy of perception of the world around the two communities is displayed.

\section{APPENDIX 3}

\section{The case of visualization of yoga practice}

In our case, we had reconstructed data on (a project on the visualization of a yoga practice):

a) intentions of the authors of the visual images,

b) the kind (quality) of an image (professional or natural),

c) the form of an image (video recordings, movies, instruction movies, drawings, photos),

d) direct natural presentations,

e) verbal descriptions and explanations triggered by visual images.

We can define the visualization category as follows: "The visualization of yoga practice involves intentional production of an image in order either to demonstrate technical moves of different poses or to illustrate technical moves accompanied by references to yoga philosophy. Images can be recorded in: video recordings, 
movies, instruction movies, drawings, photos, more elaborated advertisements, calendars with photos and pictures, etc. The immediate visualization consists of direct and natural presentations of poses to different audiences by practitioners, who also supply verbal explanations”.

\section{Diagram 1. Visualization of yoga practice: saturation of category}

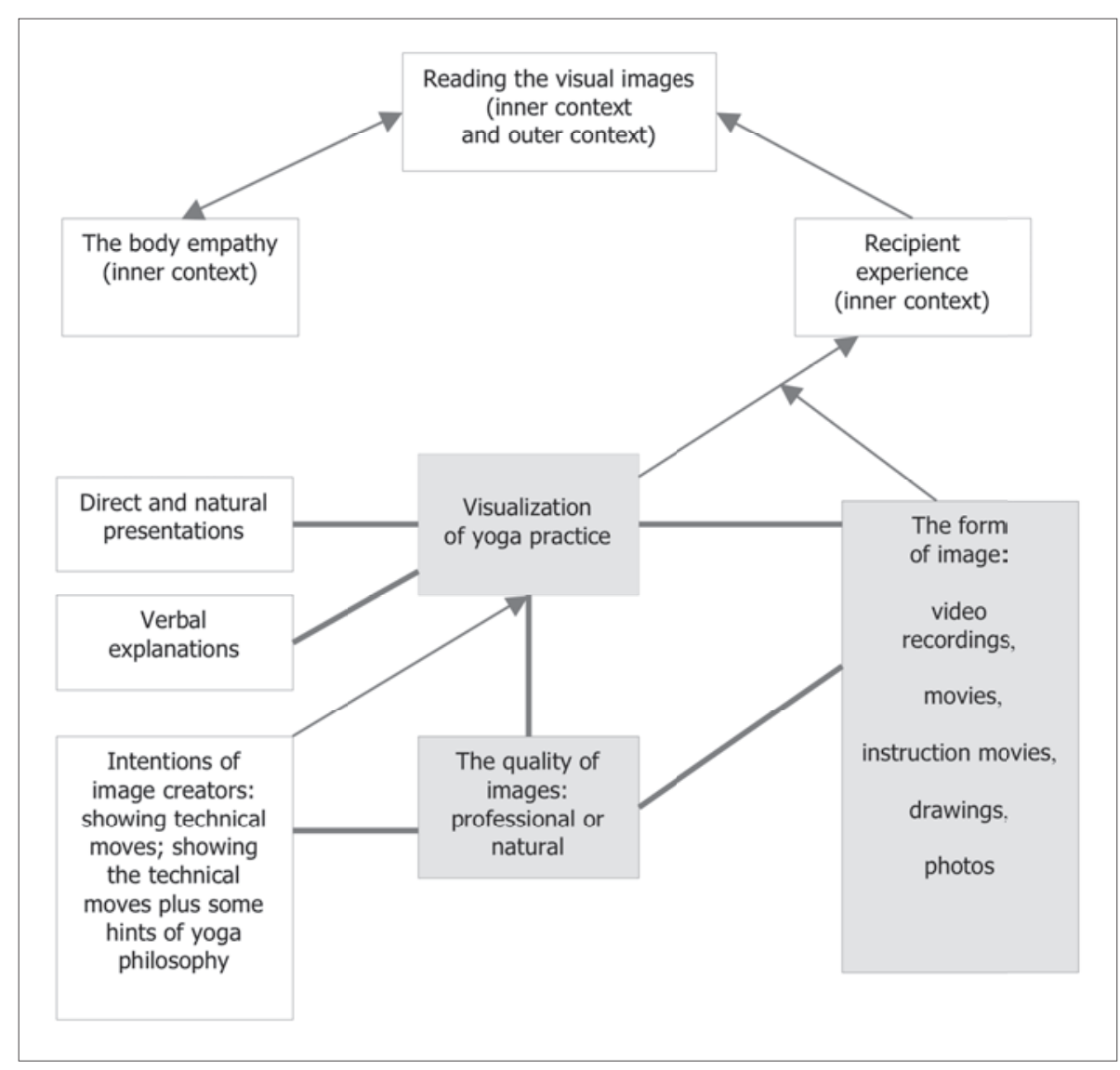

\section{Theoretical saturation and hypothetical propositions}

Data analysis prompts the following conclusion: The visualization of yoga practice is definitely a contextually situated process. If we want to saturate the category of visualization of yoga practice, we should analyze the pictures of yoga in different contexts. The fact that yoga practice is contextually organised, does not mean that a researcher can ignore basic assumptions of yoga practice and the rules of exercising diverse poses. Imagining spectator and photographer demands requires an emphatic understanding of any future recipient's visual - perceptual structure (which, in turn, requires relevant knowledge guiding our perception of an intentionally organized visualization of yoga practice). Outsiders cannot perceive what 
the competent practitioner can (as clearly demonstrated in movie-elicited interviews). So we should look carefully at each context of production of images as well at different contexts of their perception and compare the two. These contexts include the visual cultures and subcultures that should be researched/reconstructed to catch the meanings generated in inner and outer contexts.

We should then choose different recipients of yoga practice images, contrasting, for instance more and less experienced practitioners (inner context). Competent practitioners, for example, easily reconstruct the body moves from the photos or instruction movies (data from movie-elicited interviews, our research on Visualization of Yoga Practices). Analysis can prompt the following hypotheses:

- "Physical empathy can be activated by visualization of body gestures"

- “A recipient's experience in 'reading' and performing visually presented gestures forms an important condition of successful visualization of yoga practices. The more experience a practitioner has in yoga practice, the better her competence in reading further visual presentations of yoga practice"

- "The degree of physical empathy can be diagnosed by 'reading' the pictures. The closer the readings to expert interpretations, the better the practitioner's physical empathy”.

\title{
Vizualna utemeljena teorija: metodološki nacrt i primjeri iz empirijskog rada
}

\author{
Krzysztof Tomasz KONECKI \\ Institut za sociologiju, Sveučilište u Eódźu, Poljska \\ krzysztof.konecki@gmail.com
}

Utemeljenu se teoriju obično ne povezuje s opsežnom upotrebom vizualnih podataka. Autor ovog članka želi podastrijeti elementaran uvod u metodološke pojmove i procedure koji istraživačima omogućuju uključivanje vizualnih podataka $\mathrm{u}$ analizu dok osmišljavaju nacrte istraživačkih projekata u okviru utemeljene teorije. Autor također raspravlja o različitim pristupima analizi vizualnih podataka koji se služe imenom utemeljene teorije, ali zapravo ne izvode analizu u skladu s njezinim temeljnim načelima. Na početku autor opisuje neka nadahnuća koja potječu od malobrojnih istraživača koji su upotrijebili vizualne podatke pri konstruiranju teorija u stilu analize metodologije utemeljene teorije. Također se opisuje status vizualnih podataka i metodološki model analize vizualnih podataka u utemeljenoj teoriji (stvaranje slikovnih predodžbi u više isječaka). Stvaranje slikovnih predodžbi u više isječaka jest gramatika analize vizualnih pripovijesti koja naglašava sljedeće faze: a) čin stvaranja slika i slikovnih predodžbi (analiza konteksta stvaranja); b) sudjelovanje u prikazivanju/komuniciranju vizualnih slikovnih predodžbi; c) vizualni proizvod, njegov sadržaj i stilska struktura; d) recepcija »slikovne predodžbe« i vizualnih aspekata predstavljanja/predočavanja nečega. Nadalje, predstavljaju se procedure analiziranja vizualnih podataka 
u svrhu generiranja kategorija o vizualnim procesima (transkripcija, otvoreno kodiranje i pisanje bilježaka). Predstavljanje se zasniva na primjerima iz dvaju autorovih istraživačkih projekata o vizualizaciji prakse joge i vizualizaciji beskućništva. Autor također predstavlja selektivno kodiranje vizualnih slučajeva i empirijskih materijala zajedno s primjerima teorijskih bilježaka i usporedne analize. Posljednja od opisanih procedura jest teorijsko uzorkovanje koje upućuje na to kako i gdje tražiti vizualne podatke u svrhu generiranja svojstava kategorije. Članak završava zaključcima i napomenama o budućim izgledima vizualne utemeljene teorije.

Ključne riječi: vizualna utemeljena teorija, vizualni studiji, vizualna etnografija, vizualni podaci, kvalitativno istraživanje, kvalitativna analiza podataka 